\title{
Religious Popular: Umrah as Manifestation of Religious Phenomena of Coastal Communities
}

\author{
I Farihah \\ Institut Agama Islam Negeri Kudus, Central Java, Indonesia \\ \{irzumfarihah@gmail.com\}
}

\begin{abstract}
This study aims to analyze the religious motives of the Umrah pilgrims in coastal communities, whether the Umrah is only as religious accessories or has been able to place it as a substantial religion. This article uses a qualitative method with a phenomenological approach to religious coastal communities, each of which has a different experience and purpose in carrying out Umrah worship. Max Weber's social actions and the intrinsic and extrinsic religious orientation of Gordon Allport and Ross became the theory used to analyze the umrah phenomenon of coastal communities. This article results, that the worshipers have different motives in carrying out worship; first, the reason they chose Umrah as a worship service to Baitullah, was because the Hajj waiting list was very long and was not possible with conditions that were getting older; Second, performing Umrah in the Holy Land as a place of forgiveness of sins for the mistakes that have been made; Third, the Umrah worship conducted by the middle to upper classes is predominantly oriented to intrinsic religion, but some of them have found an extrinsic religious orientation. Whereas in the lower middle class, informants show the intrinsic orientation motives.
\end{abstract}

Keywords: UmrahWorship, Social Action, Religious Orientation

\section{Introduction}

Popular religion, including Umroh as Sunnah worship, is an interesting topic among Muslims today. Considering the increasing number of community's interest in Umroh, the implementation of the Umrah becomes the government's attention and the public service. The Minister of Religion Regulation No. 8 of 2018 has issued that the organization of Umrah pilgrimage can be carried out by the government and / or travel agency determined by the minister[1].

The number of Umrah bureaus offered many options of prices and diverse facilities, making the community open and free in choosing the budget to take the Umrah. As data from the plus Hajj bureau and Umrah Mas'aril Haram, aperture branch located in Paciran Village, Lamongan Regency, East Java, schedules three times to depart each year. Umrah participants since 2016 have experienced a significant increase (Interview with Agus, secretary of the Umrah bureau of Mas'aril Haram). The desire to worship in the pantura community is a spiritual necessity because worship shows evidence of obedience of a servant to the Khaliq (Allah). 
Umrah worship, as the pilgrimage practices that require actors to have the ability and readiness of various things, not only requires a healthy physical provision but also needs large costs and free time [2]. Worship is not only proof of obedience, but also part of a servant's move to become a better person. Hijrah in the Koran is interpreted to move, as in the history of Hijrah, that the process of moving the Prophet Muhammad and his followers from Mecca to Medina to avoid the pressures and insults from the Quraysh infidels in Makkah. Hijrah is done to spread Islamic teachings more freely.

Hijrah is rife today not only as a means of changing one's religious behavior, but it also requires a physical appearance that shows the identity of religious observance [3]. Salma Faatin's research on recurring Hajj by the Kudus community turned out to be motivated by many motives that were not only religious but also psychological motives related to one's psychological needs, for example wanting to get appreciation from others[4]. Duane F Reinert's research, that in the underdeveloped groups is low in religious practices and their faith in God and intrinsic religious. Whereas doctrinal groups (textual) are more obedient and involved in religious practices in addition, their intrinsic orientation is greater[5].

Some of the studies above, worship other than as proof of obedience to God, is also inseparable from the physical appearance to get recognition from others and serve as a model of religion at this time, but the phenomenon of umrah in the Lamongan coastal community continues to increase and not only those economically practiced already established (wong sugih), even people who in their simple lives are also motivated to perform umrah. Several reasons and religious orientation are the basis for performing umrah in coastal communities. whether as worship that is more trend or religious orientation of coastal communities better in various popular religious phenomena. This article looks at the phenomenon of the rise of umrah from the motivations of two classes, namely the upper-middle and lower-middle in the Lamongan coast.

\section{Method}

This study uses a phenomenological approach which is seeing reality by searching for the essence of the meaning of a phenomenon motives (not through arguments, concepts or general theories) for performing Umrah worship in the Coastal Lamongan community[6], because phenomenology emphasizes the perceptions and interpretations of one's experience[7]. The object of phenomenology is socio-cultural phenomena by starting from the things that underlie human behavior or society[8]. What appears in the behavior of the Lamongan coastal community in carrying out the current umrah worship that is crowded and carried out from various classes is a phenomenon.

Collection data is by using in-depth interviews (in-depth interviews), documentation, observation. Analysis of the data in this study began with the primary and secondary data transcript through interviews, observations, and documentation. The classification of data will be made consisting of the reasons for carrying out Umrah worship both from the upper-middle class and lower-middle class.

\section{Result and Discussion}

\section{Umrah Motivation Coastal}


The community of the north coast of Java cannot be separated from the Islamization of Java through Nine Saints(Wali Songo). Beatty's research, Javanese Islam is considered syncretistic Islam, and a combination of Islam, Hinduism, Buddhism, and animistic beliefs which were later refuted[9], in research Nur Syamwhich looked at Javanese Islam especially in the eastern Tuban region (Tuban-Palang), coastal communities have a religious specialty or known as Collaborative Islam. Where there is a relationship between Islam and local culture which is the result of construction between agents and society [10]. Coastal Islam establishes a dynamic relationship with local culture, and in practice, it does not conflict with Islamic teachings.

However, if we move to the east of the Paciran region, the shades of coastal Islam have begun to abandon local symbols. The community believes more with worship at God without going through the wasilah (interview). It has become one of the motivations of the people to perform the Umrah service, as an effort to complain to Allah for the mistakes that have been made during world life. The community realizes that the pilgrimage is important because it also takes place the Umrah, but the queue is so long, whereas they have a strong desire to immediately carry out worship in the holy land (Mecca and Medina). The implementation of Umrah worship on the Lamongan coast is not only attractive to the upper-middle class (wong sugih), but also the lower-middle class.

\section{Spirit Wong Sugih}

This study gets several informants, consisted of 5 middle and upper economic informants (symbolized $\mathrm{X}$ ), and 3 informants from the lower middle economic circle (symbolized Y). X1 works as a raw fish entrepreneur in several fish companies. The community knows him as a young, successful, and generous entrepreneur or can be categorized as a wong sugih. His business was built from the ground up with very little capital because the work ethic that the husband and wife built helped deliver their success. In 2009, X1 performed the Hajj for the first time through the Hajj bureau with offices in Surabaya. After returning from worshiping in the Holy Land, the desire and longing for the Holy Land increased. Therefore, starting in 2012, they performed the first Umrah and continues every year. Their motivation to carry out the Umrah is as a form of gratitude to Allah who bestows extraordinary pleasure to them. Starting from the enjoyment of work that is getting smoother and successful, he also gets support from a confident family. Umrah is not merely a religious ritual that they can do repeatedly every year. An inner satisfaction in every worship and concern for others is also increasing. It was also conveyed by the surrounding community, that $\mathrm{X} 1$ aside from being obedient in worshiping Allah, also caring for others (interview).

While informant X2 is a widow who does not have children. Starting in 2012 she performs Umrah every year in the month of Ramadan but had previously performed Hajj with her husband. Her motivation to perform Umrah every month of Ramadan is to get closer to Allah and ask forgiveness for her sins and she died husbands. She believes that after a human dies, all of the deeds will be cut off, except for three cases, namely sadaqah jariah, useful knowledge, and pious children. She has no children so that she wants to pray for him after he dies. Therefore, as long as she is physically and materially able, she will be closer to Allah, and one of them is performing the Umrah during the month of Ramadan.

Informant X3 works as a kindergarten teacher Aisyiyah Bustanul Athfal and her husband is a fish hatcher at the Fish Auction Place (TPI) of Brondong Village, Lamongan Regency. The pilgrimage was done twice, first before carrying out the pilgrimage, and the second after carrying out the pilgrimage. The second umrah service was held with her children. According to X3, the motivation to carry out Umrah worship, to get closer to God and inner satisfaction when carrying out worship in the holy land. For X3 in carrying out the 
Umrah, worship must be intended and there is an effort to save some of their fortunes. According to X3 that all prayers can be done anywhere, but satisfaction in carrying out worship in the holy land cannot be replaced by performing worship in the homeland. During Umrah, he and his family focus on both compulsory and sunnah worship. After returning from the holy land, there is a desire to always keep the congregational prayers in the mosque as they have done during umrah in the Holy Land.

Informant X4 is a widow who works as a trader with high morale. Before her husband died, she handled all the family business, because her husband was often sick. Umrah has repeatedly done it after carrying out the pilgrimage. But he did not want to say how many times to do the Umrah. According to him, the Umrah is pure worship and as a form of servitude to the creator, it is not important to convey to others about the implementation of the worship. Motivation to perform Umrah is to want to draw closer to Allah and gratitude for the health favors given to him at a young age.

Whereas the informant X5 who happened to be a man works as a fish hatcher at TPI Brondong Village and he is also an agent of the Al-Mansurin Amanah travel agency based in Solo. He and his wife perform the Umrah since 2016 and take place every year until now, only in 2017 they carry out the Hajj. Motivations for the implementation of repeated Umrah worship are: First, a strong desire to always return to worship in the Holy Land; Secondly, he happened to be appointed as an administrator at the al-Mansurin travel bureau, so as not to disappoint the worshipers who had joined him, so he wanted to accompany him even though using his own expense. Third, there is a feeling of satisfaction in carrying out the Umrah worship with the group and according to X5 people who enter the management in the travel can maintain the mandate properly, therefore X5 hopes to be a good and trustful person too. It has been proven when he first joined the travel agency From 2016 until 2019. According to $\mathrm{X} 5$, conducting worship and praying in the holy land has extraordinary strength and after completing the Umrah there are changes in worship and their family economy. Besides, feelings of pleasure and inner satisfaction that cannot be replaced with anything.

\section{The Spirit Wong Cilik}

The middle to lower economic circles who have performed Umrah worship has different religious reasons and experiences. For example, Y1 is a 70-year-old woman, since a teenager she worked in a family of entrepreneurs. When she married, she left the job, but her marriage ended in divorce. Finally, she returned to work in the family until now and has been considered as her own family. Since then Y1 has saved some of the salaries she has received to be able to perform the pilgrimage. After the money was collected, the pilgrimage quota increased and the queue reached 10 years, then her desire to perform the pilgrimage was undone and diverted to register the Umrah. In 2012 Y1 departed Umrah with the motivation to see the Ka'bah, the Haram Mosque, and the Nabawi mosque directly to worship by asking forgiveness for the mistakes that had been made so far. Y1 felt like a person who was not smart, so before carrying out the Umrah worship, she recited with one of the Kiai in Blimbing Village to get guidance to worship during the Umrah. Y1 seriousness in learning is applied when performing Umrah in the Holy Land. Many things affect the changes of her life after performing the Umrah, including worship pilgrims performed at the mosque or mushalla, besides it is calmer in living life even though economically including the underprivileged. A strong desire to re-do Umrah again, but the money they have is not enough.

The second informant is Y2, a widow who supports her two children. One of the children has bad behavior, drinking alcohol. After the divorce from her husband, she got a piece of land that had been bought together, because of a strong desire to be able to carry out worship in the holy land, she finally sold the land. The proceeds from the sale of the land were 
used to register Umrah and support his family. Her main motivation to perform Umrah is to pray for their children, so she can change their behavior and become a pious child. Makkah as a place to carry out rituals solemnly, as well as Medina [11]. Y2 strongly believes that praying in Mecca and Medina is more possibly answered than in Indonesia or anywhere. She also believed that worship in the holy land will get a greater reward. Y2 was happy to get to the city of Mecca and Medina and did not miss to shop for some of the city's specialty items. Coming home from Umrah, Y2 felt his worship was better and could istiqomah worshipers to pray five times at the mosque or mushalla. She felt that the mosque became his second home. When the fajr congregation prayers he will return home after praying thulu'. The remaining problem is a fact that the behavior of children cannot leave liquor.

Informant Y3 is a Kindergarten teacher Bustanul Athfal, 48 years old, and when he is at home he opens tutoring for elementary school children. The desire to go to the holy land for pilgrimage has been a long time ago, but the savings it has are not sufficient, in addition, it must wait for a queue for the Lamongan region to reach 13 years. Therefore, the money held is registered to carry out the Umrah. The main motivation for performing Umrah is to seek forgiveness for all the sins that have been done so far. Even though his praying would be heard by God, when he could deliver it in the holy land, he thought it would be better. The spiritual experience felt when carrying out the Umrah when he arrived in the holy land and the first thing he saw was the Kaaba, his feeling as if God was in front of him and cried, grateful for the pleasure of Allah given to him so far. In the holy land, Y3 prioritizes worship, because that is the first intention. Coming home from the holy land something changed in him that is more careful in carrying out religious teachings, especially carrying out congregational prayers fard. There are regrets when unable to run fard prayer congregations in mosques or mushallas. Longing for the holy land is always in his mind, therefore this year he intends to register the pilgrimage, even though the waiting time is quite long.

According to the Blimbing village community, that the rise of umrah is not only done by the wong sugih, but those who earn a mediocre income also have a strong motivation in carrying out the Umrah worship. Also, in the fishing community, divisions there are many (crew members) who begin to perform the Umrah service, even though their income is uncertain for every departure of the sea. The social care of people who carry out Umrah worship with the surrounding community, both individually and with groups is very good. It is precisely those who repeat in carrying out the Umrah, are more concerned with the underprivileged and Islamic activities carried out in the area.

\section{Religious Rationality}

Human has the tendency inherent to be always leaning on him in religion. Tendency inherent this Islam is called nature. Fitrah is a continuation of the primordial covenant between God and the human soul. The human soul is created by the consciousness of something absolute and holy (transcendent), which is the origin and purpose of everything in this world. The tendency of purity is always to want to do something of the kind, and the truth. It is related to the fact that human sanctity rests upon the purity of the Divine, and that the purity of the Divine is ever-changing [12]. God created it because religion is a necessity of human life. Indeed, humans can hold it to death. However, in the end, before the spirit leaves the body, it will feel the need [13].

Each informant who performs the umrah, of course, has his or her reason for the act (worship) that has been performed. As in Max Weber's theory of social action[14], in the instrumental rationality of the pilgrims, both those in the upper and lower-middle-class economies have a clear purpose of worshiping the holy land, wanting to pray for their 
deceased husband, to pray for his son, and also for a place of forgiveness. To achieve this goal, it is not easy for those who are working as teachers or widows who are unemployed because they have to save on the income that is sufficient for daily living. While those in the upper-middle class are trying to achieve that goal, they also want to save some of their income, but there is a budget set aside for performing worship services, without having to cut back on their daily expenses.

In terms of value-oriented rationality, the pilgrims in performing their worship have a foundation on which to stand. For example,Surahal-Baqarah verse 196 and some of the priorities of worship in the holy land were often conveyed by the Kiai during lectures. Meanwhile, in terms, of affective rationality, each of them has a different feeling. X1 felt a sense of satisfaction during the pilgrimage in the holy land, besides the longing to return home was always felt upon returning home. X2 the same feeling that X1 felt, only he felt closer to God when he was in the holy land, especially during the month of Ramadan because he felt he had no one nearby. While X3 is happy to be close to God for communicating his son's delusional issues that are out of the rules of Islam. X4 feels the joy and satisfaction of performing worship in the holy land. X5can carry out repeated umrah worship, as he can pray to God in places of necessity. While in the lower middle class of Y1, Y2, and Y3 happiness cannot be concealed when they see the live cries, they seem to believe that they can appear directly in front of the Ka'bah and other holy places.

In traditional rationality, although umrah worship is not an easy and cheap thing for everyone to do. For the upper class, when they have more money than they earn, they will choose to perform Umrah worship instead of traveling abroad which is now a trend among the rich. While for the lower middle class they cannot say this umrah worship is tradition, as being able to perform once in a lifetime has been an incredible experience. Although the desire to return to the holy land was present, they also understood the economic and age-old conditions as presented in $\mathrm{Y} 1$ and $\mathrm{Y} 2$.

The practice of umrah for the coastal community has become quite common for all people with different social classes. The upper-middle class is performing the umrah repeatedly, even annually, while the lower middle class is at least performing once in order to see the Ka'bah. Begging forgiveness to God can be done anywhere, just for coastal Muslims, it would be better if it could be delivered directly to the holy city (haromain). Therefore, the main motivation for performing worship in the holy land is feeling peace and purity of the soul.

\section{Religious Orientation}

Considering the popular religious spirit today, it is evident that both people of both classes have intrinsic religious orientations. It can be seen from their reasons: First, in performing their Umrah worship, they have the pure personal desire with family consideration. As stated by the X3 and X4 informants, they consider umrah to be his affair with God, and the main purpose is to worship the merit of Allah's decision. Second, during the performance of the Umrah worship, they maximized their time for worship and repaired their lack of worship during their homeland. Third, there is a motivation to learn about the procedure of the umrah and the prayers to be read during the worship, so Y1 studied with a Kiai before departing, because he felt that he did not understand the teachings of Islam and especially those related to Umrah worship. Fourth, guarding the worship after the umrah, including the istiqomah in performing the obligatory prayer at the mosque or in Mushalla, caring for each other through helping orphans, the poor and caring for the religious activities in the area. 
There are also external religious orientations. First, for example, Y2 orientation to performing Umrah worship is to receive a greater reward when praying or performing other worship. Second, performing umrah also strengthens the social relationship, because X5 besides performing umrah every year, is also a representative of the umrah bureau based in Surakarta.

\section{Conclusion}

Religion is popular through umrah worship performed by the coastal community of Lamongan. Although the incurred costs are small, each year their enthusiasts to perform umrah are constantly increasing. Itis not merely undertaken by the upper-middle class (the rich). The lower middle class has also motivation for performing umrah worship. In this research, rich people are motivated to perform repeated umrah, 4 out of 5 informants have performed umrah every year since he first performed umrah or hajj. Meanwhile, the three groups of the lower middle class, performed the umrah once, though their desire to return to worship in the holy land was strong, only economic factors did not support their desire. The implementation of Umrah worship can be regarded as a form of migration of a slave from a sinful life to the path of good with different religious purpose and orientation.

\section{Reference}

[1] Peraturan Menteri Agama Nomor 8 Tahun 2018. .

[2] C. Walker, "Faith Becomes Religious Adaptive Value."

[3] F. Annisa, "Hijrah Milenial: Antara Kesalehan dan Populism," Maarif, vol. 13, no. 1, pp. 38-54, 2018.

[4] S. Faatin, "Haji Dua Kali: Kajian terhadap Motif Pengulangan Haji Masyarakat Muslim di Kudus," Fikr. J. Ilmu Aqidah dan Stud. Keagamaan, vol. 7, no. 1, pp. 43 72, 2019.

[5] D. F. Reinert and J. R. Bloomingdale, "Spiritual Experience, Religious Orientation, and Self-Reported Behavior," Int. J. Psychol. Relig., vol. 10, no. 3, pp. 173-180, 2000.

[6] J. W. Creswell, QUALITATIVE INQUIRY\& RESEARCH DESIGN Choosing Among Five Approaches, Second Edi. London: Sage Publications, 2007.

[7] E. Griffin, A First Look At Communication Theory. New York: Mc Graw-Hill, 2012.

[8] H. S. A. Putra, "Fenomenologi Agama: Pendekatan Fenomenologi untuk Memahami Agama," Walisongo J. Penelit. Sos. Keagamaan, vol. 20, no. 2, 2012.

[9] A. Beatty, Varieties of Javanese religion an anthropological account. Cambridge, U.K.; New York: Cambridge University Press, 1999.

[10] N. Syam, Agama Pesisir. Yogyakarta: Pustaka Pelajar, 2010.

[11] Al Makin, "Antara Ziarah Religius dan Kapitalisasi di Era Globalisasi: Catatan Etnografis Umrah,” Afkaruna, vol. 12, no. 1, pp. 114-134, 2016, doi: 10.18196/AIIJIS.2016.

[12] H. B. Adz-Dzaky, Konseling dan Psikoterapi Islam. Yogyakarta: Fajar Pustaka Baru, 2006.

[13] M. Q. Shihab, Membumikan Al-Qur'an. Bandung: Mizan, 2014.

[14] N. Abercrombie, S. Hill, and B. S. Turner, The Penguin Dictionary of Sociology, Fifth Edit. London: Penguin Books, 2006. 
